\title{
9. Eco-tourism for sustainable development in Royal Chitwan National Park
}

The Royal Chitwan National Park with an area of 932 sq.km, situated in the inner Terai, is the first national park established in 1973 for the conservation of the greater one-horned rhinoceros (Rhinoceros unicornis). The Royal Chitwan National Park located at the junction of Paleo-arctic to the north and Oriental to the south Biogeographic realms, is with the mosaic of varied physiographic conditions of southern Mahabharat range, inner and outer Siwalik hills, valleys created by these ranges and numerous water bodies. The uniqueness of its location, having tropical and sub-tropical monsoon climate, has rendered it as a pristine natural area.70\% of Sal forest, 7\% of Riverine forest and 20\% of Grasslands dominates the vegetation coverage of RCNP. The biotic environment is not stationary, as it is an ever-changing mosaic of forests, grasslands and water bodies. The Sal forest includes the tall, stately and with straight trunks Sal trees, Shorea robusta, having the average height of $30 \mathrm{~m}$. Riverine forest extends right up to the water edges and on gravel islands in the middle of the watercourses of the Narayani, Rapti and Reu river systems and it covers about $7 \%$ of the total vegetation coverage in the park. Dalbergia sissoo and Acacia catechu dominates this forest. The Grasslands contain over 70 different species of grasses that are collectively called 'Elephant grass' because numerous species grow $6 \mathrm{~m}$ high in places. The dominating grass species is Saccharum spontaneum, which is the hardy coloniser. The aquatic habitats of RCNP and its buffer zone have 135 species of fishes, which is about $75 \%$ of the total 179 species known to exist in Nepal. The 9 Amphibian species found are comparatively poor in comparison to 42 Reptiles known to exist there. Chitwan is a paradise for bird-watchers and ornithologists, and is one of the most rewarding places in the world for watching and carrying out detail studies. 526 species of birds have been recorded in RCNP. The National Park supports 56 species of large and small mammals including endangered rhino, elephant and numerous deer species. Out of the existing 56 different mammals, there are 30 species of CITES categorised mammals in RCNP. Eco-tourism expressed a wide range of aspirations toward environmentally friendly travel, soon to be reflected in wide-ranging controversy. Tour operators seized the term gladly, ascribing it to practically any small-scale operation in a rural area. Tourists trusted that vacations with the Eco-prefix might somehow be less harmful to the environment than those without. Environmentalists, perhaps unfairly, derided both for naivety and pretension. The main attraction of RCNP is its wilderness, forests, grasslands and wetlands with great opportunities to sight innumerable varieties of wildlife in their pristine natural habitats. Tourism is mostly developed in the eastern, central and western sectors from Sunachari to Amaltari. This is because of its easy approach as the East-West highway (Mahendra highway) goes through north of RCNP. There is no tourism in the southern sector of the park in the Madi area. There are nine entrance gates from where RCNP could be entered, all along the northern border. RCNP's list of attractions like its magnificent wildlife, its lovely wilderness, grasslands, forests, wetlands, beautiful landscapes, beautiful views of Himalayan mountains from there, elephant and jeep safaris, visit to Tharu villages, Tharu culture, Tharu music and 
dances, handicrafts etc. are very popular among the visitors of RCNP. This long and varied list can be advertised, popularised and marketed as one of the greatest tourism products of RCNP. At present tourism in RCNP is very important as it hosts more that 100,000 tourists which is about $23 \%$ of the total number of tourists that arrive annually in the kingdom of Nepal. This has affected the economy of the country itself. Many people in the area are engaged in the tourism-related business, which has been a great source of livelihood for them. RCNP being home of many endemic wildlife is not only the asset of Nepal but also of the whole South Asia and the world as well. United Nations Education, Social and Cultural Organisation (UNESCO) have declared it "World Heritage Site" and it is the first National Park of the kingdom. Undoubtedly, the tourism development in this region since last three decades has brought about economic development of the region and of course this will continue in the future as well. However, the time has come for us to proceed to scientifically and carefully manage activities. This is partly because the culture, which has evolved over centuries, could be polluted beyond redemption and partly because the pristine ecosystem and ecological niches of RCNP could be the victims of overload and proceed beyond the carrying capacities of the region as well.

There are more than 2,670 national parks and wildlife reserves throughout the world covering about $39,973,163$ sq. $\mathrm{km}$ of the earth's land area, but the problem of good management has remained unsolved. Recreational and ecological impacts like impacts upon soil, impacts upon water, impacts upon animals and plants were accounted along with their mitigation and management Major impacts of tourism on the natural environment of RCNP includes concentration of tourists in one sector; concessionaire hotels in prime wildlife habitat areas; vehicular and jungle drive impacts; impacts from domestic elephants and elephant safaris; impacts from canoeing and river pollution, impacts from exotic plants; development of prostitution, gambling and drug abuse. Tourism is also not free from adverse consequences like any other large-scale human activities although it is considered as a smoke-less industry. Therefore, undoubtedly, tourism has impacts upon the land, vegetation and wildlife in the areas where it occurs. The environmental consequences of tourism are often difficult to isolate from other developmental activities. It has been noted that tourist density can be devastating to the host ecosystems especially in ecologically sensitive areas like Sauraha in RCNP. However, RCNP with its still near pristine ecosystems has been an excellent recreation ground for many tourists who arrive here every year and this has affected the economic development of the people, park and the country itself. And, eco-tourism is the one and the only concept that is necessary for the sustainable development or the Royal Chitwan National Park.

Ramesh Shrestha

Central Department of Zoology Tribhuvan University, Kathmandu 